\title{
When Things Don't Fit: Looking at the London VlithrientuIII
}

by Hugh Bowden
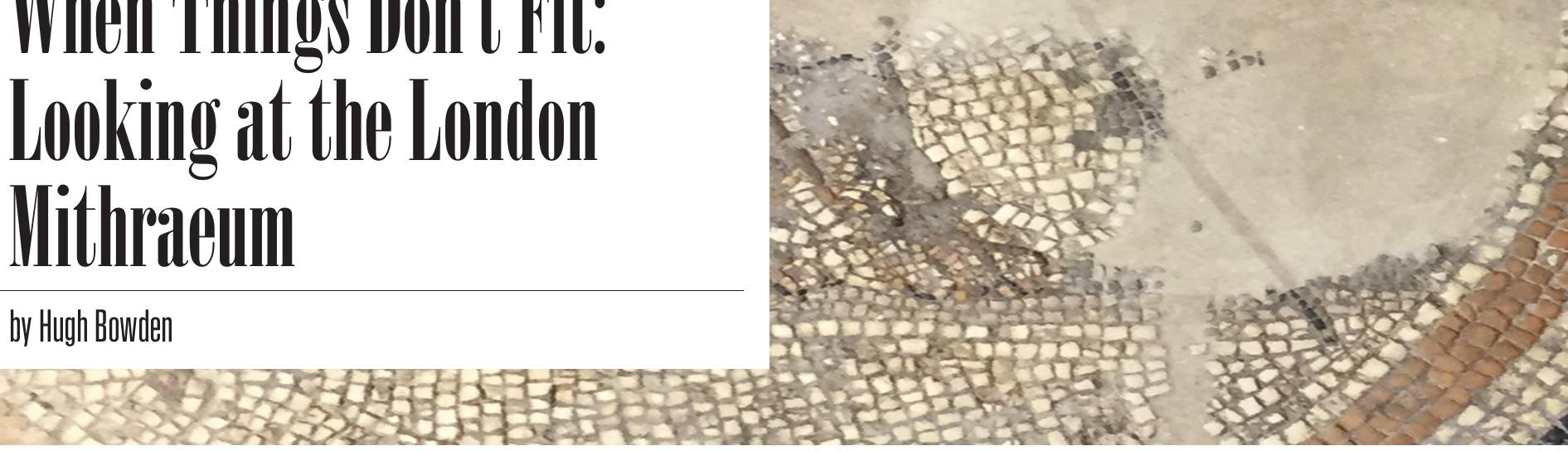

$\mathrm{T}$ he redisplayed London Mithraeum beneath the Bloomberg building in the City of London, and the material recovered from excavation of the site, now on display in the Museum of London, provide a valuable resource for exploring aspects of religion in Roman London. And they are well worth the visit, not least because they are free to the public. Inevitably the information provided with the artifacts and the site itself emphasise what we know about them. But there are puzzling features of this material, and there is a lot that we do not know. I want to discuss some of these puzzles, not with the aim of providing answers, but to remind us that there is still plenty to be discovered about ancient religion, and also that our perspective on the ancient world is always affected by accidents of survival.

On $28^{\text {th }}$ October 312 at a crossing of the River Tiber just to the north of the city of Rome, a Roman general, Constantine, who six years earlier had been hailed as emperor at York, claimed victory over a rival claimant to the throne, Maxentius. One of the best-known episodes in the story of the battle is told in Eusebius' Life of Constantine and elsewhere: sometime before the battle Constantine saw a vision of a cross above the sun, with the words 'In this sign, conquer' inscribed on it. Inspired by this, he converted to Christianity, and rode to victory. At more or less the same time, half an empire away in London, the Mithraeum on the banks of the Walbrook collapsed, and worship of Mithras there came to an end. So the triumph of Christianity and the collapse of Mithraism appear to have coincided. But history is rarely so neat, and this article is about things not fitting together.

Let us go back briefly to Constantine. The earliest account of his solar vision actually dates from years before the Battle of the Milvian Bridge. A panegyric delivered in Trier in 310 to celebrate the fifth year of his reign as Augustus describes how Apollo had appeared to Constantine offering him laurel wreaths and foretelling a long and glorious reign. Apollo was a sun god, and throughout his reign Constantine continued to honour the Sun. The panegyric explained the changes he made to what could be done on a Sunday not because of its significance to Christians, but as a way of honouring the Sun. And in doing this he was following his predecessors: over the course of the third century, the cult of Sol Invictus had grown, and was particularly associated with the emperor. As rule of the empire was transformed from what was nominally a partnership between the Senate and an emperor, whose powers it granted, into a military autocracy, so at the same time the divine sphere was gradually rethought as the dominion of the all-seeing, all-controlling Sun. In this world, divine figures associated with the Sun were particularly worth cultivating, and these included Mithras. We are encouraged to think of the worship of Mithras in terms of the private concerns of individual initiates, but it had another dimension. Whatever the initiates may have learned from the Pater of their Mithraic group, they will have known that a god who was a companion of the Unconquered Sun was close to the centre of divine power.

What those responsible for the London Mithraeum in the early fourth century thought about Mithras we cannot be certain, but it is clear that they could not afford to repair his temple after a major collapse. The imminent triumph of Christianity was not a factor in this - and indeed the coincidence with Constantine's triumph was only approximate, as the collapse could have happened up to ten year earlier, or ten years later. The building was repaired, and was apparently converted into a temple of Pater Liber, or Bacchus. But what was a disaster for the Mithraists was a great benefit for archaeologists and historians of Roman London. Before they gave up the building site to its new owners, the last initiates of Mithras dug pits in the floor, and carefully buried the sculptures that had decorated it. No doubt anything made of metal was taken out and reused, but we can assume that what was buried in the pits represented everything from the temple that had been made of marble, or had some other significance. Building work in the nineteenth and twentieth centuries brought these buried marbles to light. They must have contributed to the experience of the men who met in the Mithraeum, so are worth examining. 
In 1889 three items came to light. One is described as a 'Water-deity', and is 'the upper half of an elderly male figure', $343 \mathrm{~mm}$ high and $266 \mathrm{~mm}$ wide, to quote the description in the publication of the later excavations. He is reclining, and holding a bullrush. His right arm is broken off, and this might have happened at some point after the deposition, but otherwise the sculpture seems in good condition. It is likely that it was carved as the top part of a sculpture, the rest of which was made of some other, cheaper, stone or stucco - the rest of the figure was presumably draped, or submerged, and only the bare flesh was made of marble. The second sculpture is described as a 'Genius', and is a statuette missing its head - when the head disappeared is not knowable. In its current state it is $585 \mathrm{~mm}$ high. The figure is male, and his right hand holds a libation dish over an altar, with a snake rising behind the altar and wrapping around his wrist. His left arm cradles a cornucopia, and next to him is the prow of a ship riding on waves. The third 1889 discovery is the best known. It is a relief, $432 \mathrm{~mm}$ high and $508 \mathrm{~mm}$ wide, depicting the Tauroctony, that is Mithras Killing the Bull. It is in good condition, although the most fragile points, the tail of the bull and the raven which would have sat above Mithras' cloak, are missing. We will come back to this relief, because it has an important inscription on it.

When the site was excavated in 1954, five more marbles were discovered. There is a small statue group depicting Mercury sitting on a rock with a ram and a tortoise, the raw ingredients, one might say, for a lyre. He is holding a money-bag in his left hand, and would have had a metal caduceus in his right. It is a small piece, $254 \mathrm{~mm}$ high. Then there is a head of the god Serapis, $431 \mathrm{~mm}$ high including his modius (flowerpot) headdress. Like the 'Waterdeity' this was designed to fit on a statue (or a bust) of some other material. There is a female head, $253 \mathrm{~mm}$ high, identified as of Minerva, because the top of the head was clearly designed to have a metal helmet on it: like Serapis, this would have been part of a larger piece. On what was scheduled to be the last day of the excavations, a third head was found, of Mithras. This is what confirmed to the excavators that the building now on display was a temple of Mithras. It is $369 \mathrm{~mm}$ high, including the hat, so roughly on the same scale as Serapis and Minerva, that is about human scale, and like them intended to be part of a larger composition. All three heads were in good condition, although the neck of Mithras was cut off at the time that the items were buried - both parts were found together. Finally a right hand was found, holding the pommel of a dagger, which would have had a metal blade. It is just over life-size. Alongside these marbles was found a further piece of carved stone, a left hand and forearm, somewhat less than life-size, carved in 'pisolithic limestone of Jurassic type, probably from the Cotswolds'.

The excavations of 1954 determined that the temple had been constructed around 240-250 CE, and so worship of Mithras there had not lasted more than about 80 years. But the marble sculptures came from another time and place. The heads of Mithras and Serapis, and the Tauroctony, might date to the later second or the early third century. The backs of both heads were remodelled at some point, which suggests that they were not originally intended to end up in the London

Mithraeum. The other marbles are earlier, probably from the middle of the second century. The stone is the same in all cases, described as 'fine-grained saccharoidal marble, probably from Carrara, Italy'. There would have been no-one in Britain capable of carving of this quality, and it was probably carved in Italy - with the possible exception of the relief.

Although there are examples of representations of these deities (with the exception of Minerva) in other Mithraic contexts, this does not look like a coherent set of images. They differ in date, in size and in style. So what we appear to have here is a partly random collection of Italian sculptures imported into Britain at some point in the first half of the third century. Who imported them? The only name we have comes from the inscription on the relief: Ulpius Silvanus (miles) factus Arausione emeritus leg(ionis) II Aug(ustae) votum solvit. The best translation is probably 'Ulpius Silvanus, veteran of Legio II Augusta, recruited in Arausio, has fulfilled his vow'. Some scholars want factus to mean 'initiated', but there are no parallels for this. Arausio was the name for Orange, in southern France, and the Legio II Augusta was particularly associated with the town. It was based in Britain after the arrival of the Romans, with the main base at Caerleon. From there it provided administrative staff for the Roman governor in London. A reasonably successful military career may have taken the young Ulpius Silvanus from the olive groves of Provence to the mud of the South East of England. After his retirement, he may have decided to use what money he had to create a

Mithraeum, of which he would, we may assume, have been the leader, the Pater. He may have commissioned the relief that bears his name - but in Orange, probably, certainly not in London. The rest of the sculpture for the temple he might have been picked up second-hand, as it were, either in Italy or perhaps in some merchant's shop in London, imported by other people over the years. The whole process must have been quite drawn out: the temple was built several decades after the relief was carved. And it is possible that Silvanus, who presumably retired in his forties sometime around 200 CE, was already dead by the time the site for the temple became available. However things happened, we can say with some confidence that, with the possible exception of the tauroctony relief, the sculptures were not made especially for a Mithraic temple in London. There is a sculpture of a River God, but it is not Father Thames. There is a 'Genius' by a ship, but it is not the Genius of the Port of London. Mercury is the god of merchants and tradesmen, but it was not British-based traders that the sculptor who made it had in mind.

These marble sculptures are now on display in the Museum of London, gathered together in a display case that was originally designed to echo the shape of the apse of the Temple of Mithras. The arrangement of the objects aims to be symmetrical, with the head of Mithras at the top in the centre, flanked by the other two heads, and with Mercury below it. The relief is in front of Mercury, and the 'River God' and the 'Genius' are on each side of him. Two small limestone altars also found at the site complete the display. The arrangement, backed by a curved wall of pale-coloured plaster, looks something like the display of antiquities you might find in an English country house, acquired as souvenirs of the Grand Tour. And perhaps this is a good way to think about them, given how the Mithraeum sculptures probably made their way from Italy to Britain as objects for display in a new and possibly 
incongruous situation. But it does not tell us anything about how the sculptures were actually arranged within the temple. And the display excludes some of the finds, most noticeably the marble right hand and the limestone left hand that were buried near each other and near the head of Mithras. We need to think a bit more about these items.

The focal point of any Mithraeum was the tauroctony, the depiction of Mithras killing the bull. In some surviving examples, it took the form of a painting on the rear wall of the space, but in others, including, we assume, in London, it would have been sculpted in the round. In London in the middle of the third century it would have been impossible to find a craftsman who could carve such a group out of marble, even if the marble could be found. But there were alternatives. It is likely that the tauroctony in the London Mithraeum, like some of the other sculptures, (at least originally) was acrolithic. Marble was the best medium for representing human skin, but other materials, like stucco or plaster, would be satisfactory for clothing, and for representing animals. So it would be reasonable to expect Mithras' head and hands to be made from marble, painted to look more lifelike, with the rest of the composition made from cheaper material that was easier to work with. And we do indeed have a head of Mithras and two hands amongst the items carefully buried when the Mithraeum was turned over to another purpose. But for understandable reasons scholars have been reluctant to accept that these were the elements of an acrolithic tauroctony. The head of Mithras is about life-size, but the right hand is larger than life, and the left hand, carved from local limestone rather than marble, is considerably smaller. Here is something else that doesn't fit. It has been suggested that the right hand holding the dagger might have been displayed in the Mithraeum in isolation: it was a representation of the act of killing that somehow stood for the whole scene. But there is no other example of this known. It has been suggested that there were two tauroctonies in the temple, or that the 'head of Mithras' was actually the head of one of his companions, Cautes or Cautopates, and that the rest of Mithras was in proportion to his surviving right hand. We cannot, however, escape the fact that one head and two hands, and no other element of a tauroctony, were buried on site. The simplest explanation is that these were components of a tauroctony.

Whoever put it together in London, whether it was Ulpius Silvanus or someone else, had acquired a right hand and a head of good quality marble, but no left hand. They therefore commissioned a left hand in local stone, and had the rest of the composition made out of material that would not last. Such a Frankensteinian image might look rather unimpressive in the light of day, but in the gloom of a Mithraic temple, lit only be torches, perhaps it would have been acceptable.

The incongruities of the London Mithraeum do not end with the tauroctony. This was one of the largest temples of Mithras surviving from anywhere in the Roman world. And yet it was built on land by the banks of the Walbrook and near the Thames that was damp and unstable. In the roughly 80 years of its existence it was constantly being repaired. In the end, we can guess, there were too few people using it, and too little money available to keep it usable. We think of ancient temples, especially those associated with secret rites, as somehow grand and mysterious, and imagine that participants will have been filled with a sense of awe. Perhaps what the initiates at the London Mithraeum felt above all was cold, and damp, and disappointed. Their temple was built with plenty of ambition, but rather less wisdom, and probably too little money. Modern visitors to the site, as curated by Bloomberg, may well get more from the experience than the men it was built for.

The relationship between art and religion is often complicated. Any visitor to the London Mithraeum should take the opportunity to visit the religious building on the other side of the street, the church of St. Stephen Walbrook. The church was designed by Christopher Wren in the 1670 s, and although the exterior is very plain, the interior is one of Wren's masterpieces. The main body of church is square, with a large dome above, supported on 12 Corinthian columns. There are windows with clear glass, and in obvious contrast to the Mithraeum, the space is full of light. Directly beneath the dome, raised on a base with two steps, dominating the space, is a massive round stone altar, surrounded at a distance by two circles of benches. Like the Mithraic sculptures, the altar is carved from Italian marble, in this case Travertine, and it was created by Henry Moore, arguably Britain's greatest sculptor: it is a work of art. Whether it was actually an altar as understood by the Church of England was something that had to be determined by the courts, when the stone was installed in the church in the 1980s. Wren's original design had a communion table at the east end, as is normal in churches, in front of a reredos which is still in place, with painted panels displaying the Ten Commandments. The body of the church would have been filled with box pews, cubicles for families to sit in while they listened to sermons, the central focus of services in the seventeenth and eighteenth centuries. There were many critics who opposed the installation of the Henry Moore altar, essentially on the grounds that it was inappropriate for a Wren Church, that is, that it does not fit. Although that may be true in historical terms, the new arrangement is harmonious, and the circular altar beneath the circular dome looks as though it could have been intended from the start. As an inscription in the church explains, the altar was commissioned by the then Churchwarden of the St. Stephen Walbrook, the very wealthy property developer and patron of the arts, Peter Palumbo. We can contrast his achievement with that of the man we think of as patron of the Mithraeum, the retired centurion Ulpius Silvanus. He may have had ambition, but he had little wealth, and his Mithraeum was probably never one of the must-see sights of Roman London in the decades of its existence.

Hugh Bowden, Professor of Ancient
History, King's College London
hugh.bowden@kcl.ac.uk

\section{Further Reading}

Oikonomides, A. (1975). Mithraic Art: A Search for Unpublished and Unidentified Monuments. Chicago.

Pearce, J. and Bowden, H. (2017). 'Seeing the gods in Roman London' in B. Quash, A. Rosen and C. Reddaway (eds.) Visualising a Sacred City. London.

Shepherd, J. (1998). The Temple of Mithras,

London: Excavations by W.F. Grimes and

A. Williams at the Walbrook. London. 